\title{
MedChemComm
}

Check for updates

Cite this: Med. Chem. Commun. 2019, 10, 1678

Received 24th May 2019,

Accepted 10th July 2019

DOI: 10.1039/c9md00292h

rsc.li/medchemcomm

\section{Glycans in drug discovery}

\author{
Pablo Valverde, ${ }^{a}$ Ana Ardá, ${ }^{a}$ Niels-Christian Reichardt, ${ }^{b}$ \\ Jesús Jiménez-Barbero (iD *acd and Ana Gimeno (iD *a
}

\begin{abstract}
Glycans are key players in many biological processes. They are essential for protein folding and stability and act as recognition elements in cell-cell and cell-matrix interactions. Thus, being at the heart of medically relevant biological processes, glycans have come onto the scene and are considered hot spots for biomedical intervention. The progress in biophysical techniques allowing access to an increasing molecular and structural understanding of these processes has led to the development of effective therapeutics. Indeed, strategies aimed at designing glycomimetics able to block specific lectin-carbohydrate interactions, carbohydrate-based vaccines mimicking self- and non-self-antigens as well as the exploitation of the therapeutic potential of glycosylated antibodies are being pursued. In this mini-review the most prominent contributions concerning recurrent diseases are highlighted, including bacterial and viral infections, cancer or immune-related pathologies, which certainly show the great promise of carbohydrates in drug discovery.
\end{abstract}

\section{Introduction}

Glycans are essential biomolecules in nature. They can be found as simple monosaccharides or forming more complex structures such as naturally occurring glycoconjugates, where the sugar moieties are attached to proteins or lipids. Being the most abundant molecules in living organisms, carbohydrates play many important biological roles, including their function as an energy source through glucose metabolism or as a structural component of cell walls. ${ }^{1}$ It is noteworthy that the biological roles of glycans go further beyond. ${ }^{2}$ Complex glycans are required for the proper folding of newly synthesized polypeptides and are involved in the stability, solubility and trafficking of the final glycoproteins. Moreover, being at the surface of all types of cells, carbohydrates drive critical biological functions that rely on the specific recognition of glycan structures by other biomolecules (Fig. 1). These interactions are fundamental and trigger important processes including cell signalling, proliferation and differentiation or tissue development. Indeed, the molecular recognition of glycans is at the heart of pathological processes such as bacterial adhesion, viral infection, inflammation or immune system activation. ${ }^{3}$ Consequently, either involved in self- or non-selfrecognition, glycans are attractive targets for a wide range of

\footnotetext{
${ }^{a}$ CIC bioGUNE, Bizkaia Technology Park, Building 800, 48162 Derio, Bizkaia, Spain. E-mail: ijbarbero@cicbiogune.es

${ }^{b}$ CIC biomaGUNE, Paseo Miramon 182, 20014 Donostia, Gipuzkoa, Spain

${ }^{c}$ Ikerbasque, Basque Foundation for Science, 48013 Bilbao, Bizkaia, Spain

${ }^{d}$ Department of Organic Chemistry II, University of the Basque Country, UPV/ EHU, 48940 Leioa, Bizkaia, Spain
}

medical applications. In fact, carbohydrates are more and more recognized as hot spots for biomedical intervention in drug discovery programs. However, in balance with their biological roles, the exploitation of sugars as biomedical targets has been poorly developed. Certainly, the molecular basis governing glycan functions is still not fully understood, probably as a consequence of the huge structural complexity and heterogeneity of glycans.

The wide variety of monosaccharides which can be differently linked, together with the non-template driven glycan biosynthesis, increases the number of glycan structures present in nature. In fact, glycosylation in life is a complex process which varies among different cells and tissues and is affected by cell microenvironment. ${ }^{4,5}$ These factors have hindered the methodological evaluation of the glycome and have slowed down the progress in glycosciences. ${ }^{6}$ Nonetheless, advances in glycan synthesis and the development of highly sensitive and informative analytical tools are providing increasing knowledge in the complex correlation between glycan structure and function. The progress in MS instrumentation allows mapping of glycan attachment sites, profiling glycan structural variations, and determining detailed fine structures of carbohydrates. ${ }^{7}$ In addition, new synthetic strategies have allowed access to pure and high amounts of defined complex glycan structures. ${ }^{8}$ The combination of these novel synthetic approaches with high-throughput screening methods, such as those based on microarrays, ${ }^{9}$ has become a potent tool for the discovery of glycan receptors and the study of structure-activity relationships. Moreover, the progress in high-resolution techniques including NMR, X-ray or EM has revealed fine structural details controlling glycan recognition. 
A

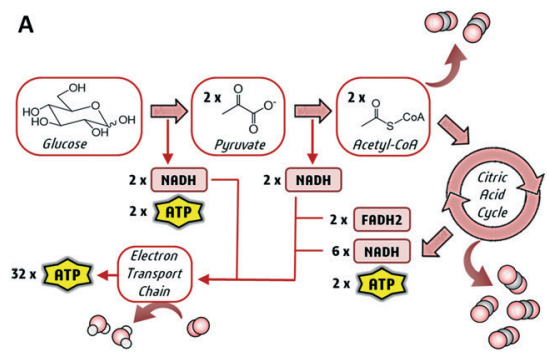

B

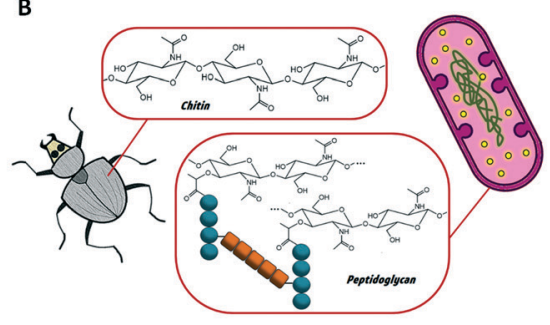

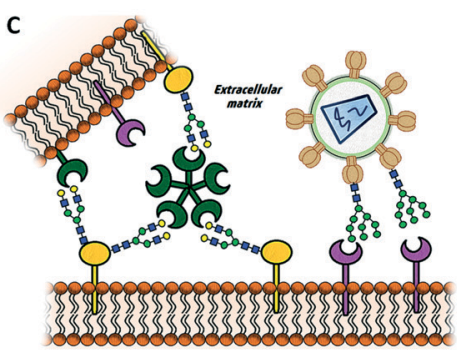

Fig. 1 Three main biological roles of glycans as (A) energy source, (B) structural elements and (C) molecular recognition elements in cell-cell and cell-pathogen interactions.

In parallel, computational tools are being developed for the refinement of X-ray crystal structures containing glycans ${ }^{10}$ and the revolution in electron imaging methods approaching atomic resolution has provided access to glycoconjugate images. ${ }^{11}$ Similarly, technical advances in sensitivity and resolution and the use of labelling strategies have allowed addressing NMR studies of large saccharides that provide a much more accurate $3 \mathrm{D}$ view of the glycan structure and conformation. ${ }^{12}$ Moreover, specific NMR experiments including STDNMR, trNOESY or those focused on protein-based methods have been successfully designed to characterize glycan interactions in solution. ${ }^{13}$ Major endeavours are being applied to study these interactions under mimicked physiological conditions $^{14,15}$ or even using living cells. ${ }^{16}$ The growing understanding of structure-activity relationships is triggering a boost in the application of glycans in medicinal chemistry. We and others have reviewed the most prominent contributions to the design of glycomimetics, glycan-based vaccines and therapeutics and highlighted the great promise of carbohydrates in drug discovery. ${ }^{17}$ This non-exhaustive review also aims to show the recent advances in the field over the past years, which definitely show the biomedical relevance of carbohydrates. Small molecule glycomimetics, glycopeptides and glycoproteins as well as a brief description of carbohydratebased vaccines are included.

\section{Small molecule glycomimetics}

Heparin and mimetics. Heparin is the oldest carbohydrate-based drug in the market and is one of the most prescribed drugs described today as anticoagulant. ${ }^{18}$ Heparin binds and activates antithrombin, a protease inhibitor of the coagulation cascade; however, the structural heterogeneity of heparins is fairly known and may entail potential problems associated to the purity and safety of commercial heparinbased drugs. ${ }^{19}$ Thus, their undesired pharmacokinetic properties, low oral absorption and side effects have exhaustively promoted searching for glycomimetics with improved features. $^{20}$ In 2001, GlaxoSmithKline registered fondaparinux as a new antithrombin drug called Arixtra, ${ }^{21}$ a glycomimetic which was designed using the natural pentasaccharide sequence responsible for the activity of heparin as template (Scheme 1). Other potential applications of heparin, heparan sulfate and chondroitin sulfate proteoglycans have also been investigated. ${ }^{22}$ In this regard, the pentasaccharide fondaparinux is one of the candidates proposed as a therapeutic ligand for targeting the leukocyte common antigen-related protein (LAR), a type IIa protein tyrosine phosphatase (RPTP) involved in several neuron processes like axon extension and regeneration. ${ }^{23}$

Fondaparinux is a particular case of a structurally welldefined heparin, ${ }^{24}$ but as mentioned above, heparins are generally polydisperse drugs prepared from animal tissues. ${ }^{25}$ Research is still pursuing the development of efficient synthetic methodologies to produce monodisperse heparin oligosaccharides in large scale, both natural fragments and modified scaffolds. In fact, notable advances are enabling the synthesis and evaluation of new heparin-like fragments as potential therapeutics. The incorporation of one-pot-based strategies ${ }^{26}$ and iterative synthetic schemes has permitted an easier and faster access to very large heparin-like oligomers. ${ }^{27}$ Moreover, the programmed inclusion of different protective groups at specific positions allows further modifications of the original macromolecules. ${ }^{28}$ Some of these modifications also include heparin labelling to facilitate the purification steps ${ }^{29}$ or tagging to monitor the tissue distribution of heparin-based therapeutic candidates in biological studies. ${ }^{30}$ Additionally, enzymatically driven protocols have allowed the synthesis of large libraries of heparin oligosaccharides ranging from 6 to 9 sugar units and with different sulfation patterns. ${ }^{31}$ Also, monodisperse heparin sulfate with anticoagulant activity has been directly prepared in human cells by recombinant expression of human serglycin. ${ }^{32}$ All these methodologies have permitted a thorough analysis of those structural factors affecting heparin binding to relevant biomedical targets, especially the position/distribution or amount of sulfate groups in the heparin scaffold. Precise attention has been paid to the interaction of heparin fragments with tau, $\beta$-amyloid and $\alpha$-synuclein aggregates, ${ }^{33}$ the proangiogenic cytokines VEGF165 and FGF-2, ${ }^{34}$ the chemokines CXCL8 and CXCL12 (ref. 35) or the Robo1 receptor. ${ }^{36}$

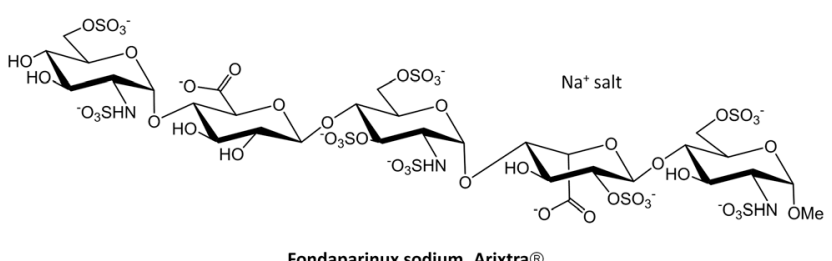

Scheme 1 Chemical structure of fondaparinux sodium salt, commercially known as Arixtra. 
Targeting pathogen glycan receptors. Nowadays, the most successful drugs based on sugar moieties are probably the antiviral compounds zanamivir (Relenza) and oseltamivir (Tamiflu). Both compounds are competitive neuraminidase ligands which are able to block the enzyme binding site and prevent the release of the virus particle from the host cell. Among pathogen infection mechanisms, bacteria commonly resort to the recognition of host glycans by cell-surface adhesins. ${ }^{37}$ Thus, glycomimetics able to interfere with or block this interaction have been designed as antagonists of microbial adhesion. The pathogen Pseudomonas aeruginosa, infecting lung immunocompromised patients, employs its lectins LecA and LecB (also called PA-IL and PA-IIL, respectively) as virulence factors and biofilm building blocks. Thus, these receptors represent significant therapeutic targets for anti-adhesive treatment, and compounds aimed at competing with human glycoconjugates have been developed. Indeed, the tetrameric structure of LecA and LecB, with pairing of neighboring binding sites at $29 \AA$ and $41 \AA{ }^{38}$ respectively, has stimulated the design of multivalent templates as anti-pathogenic agents. ${ }^{39-41}$ Additionally, key insights have been gained over extensive structural studies allowing access to potent monovalent small molecules. ${ }^{42}$ For instance, C-glycoside nM inhibitors bearing sulfonamide aglycones at the $\mathrm{C} 6$ position have been reported for LecB (Fig. 2). ${ }^{43}$ Moreover, these compounds displayed important drug-like properties such as good oral bioavailability, metabolic stability and low toxicity.

While LecB displays strong affinity for Fuc-containing oligosaccharides, LecA is a galactose-specific lectin. The systematic analysis of monofluorinated galactopyranosides where the hydroxyl groups of the natural sugar were replaced one by one allowed establishing the fundamental sugar interacting features and provided the basis for designing potent and stable glycomimetics for LecA. ${ }^{44}$ Interestingly, Titz and coworkers have reported a covalent inhibitor bearing an electrophilic epoxide, which exploits the reactivity towards a specific cysteine residue on the carbohydrate binding domain of the protein. This irreversible covalent bond with LecA permanently blocks the protein activity (Fig. 3). ${ }^{45}$

Among bacterial diseases, one of the most widely occurring infections results from the interaction between FimH, a lectin located at the tip of bacterial type 1 pili, and mannosylated glycoproteins on the urothelial mucosa. The first crystal structure of FimH bound to butyl mannose was described in 2005 and established the basis for sugar binding. ${ }^{46}$ The mannose is located in a deep pocket surrounded by hydrophobic resi-

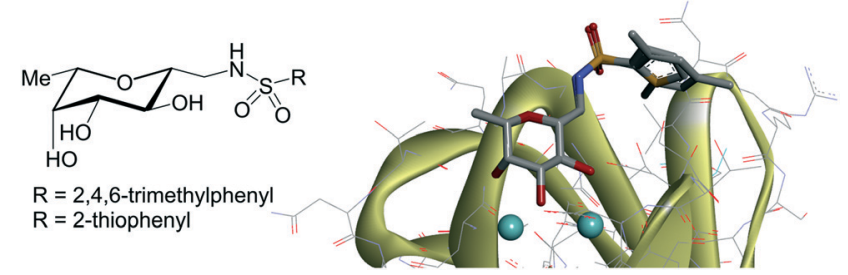

Fig. 2 C-glycoside inhibitors of LecB bearing sulfonamide moieties. X-ray crystal structures of the interaction with LecB (pdb 5MB1 and 5MAY).

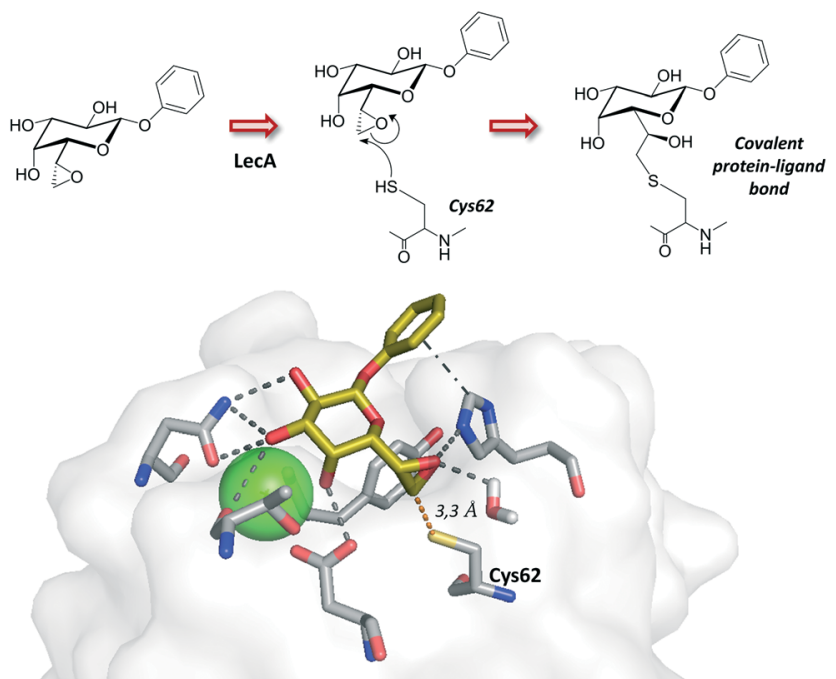

Fig. 3 Covalent inhibitor described for LecA. The crystal structure for the non-covalent mode interaction is depicted (pdb 5MIM).

dues (also known as tyrosine gate), whose architecture has been exploited to design potent inhibitors. In fact, compounds bearing aliphatic or aromatic aglycones attached to $\alpha$-D-Man have been synthesized and evaluated as potential drugs. ${ }^{47}$ The use of fluorinated aglycones, which maximize $\pi-\pi$ stacking with the tyrosine gate, provided low $\mathrm{nM}$ antagonists with the best affinities reported to date (Fig. 4). ${ }^{48}$ In addition, prodrugs with improved oral bioavailability were also obtained by phosphorylation of FimH antagonists. ${ }^{49}$

Traditionally, common strategies for the design of potent glycomimetics have been focused on enhancing the contribution of the binding enthalpy by increasing the number and strength of protein-ligand interactions, thus providing higher affinities. However, this conception is changing in medicinal chemistry and it is moving towards the further analysis of the binding entropy contribution. In the case of FimH antagonists, septanose glycomimetics provided much the same $\mathrm{H}$-bond network as that of their parent hexoses but suffered from entropic penalties due to the rigidification of the molecule upon binding. ${ }^{50}$ Furthermore, tools such as KinITC have recently emerged for evaluating the binding kinetics, parameters which have been usually neglected. ${ }^{51}$

Targeting human glycan receptors. Relevant discovered glycan-related drugs also include those targeting human lectins such as the selectin inhibitors rivipansel and uproleselan. Both molecules are in late-stage trials for the treatment of sickle cell anemia and acute myeloid leukemia,

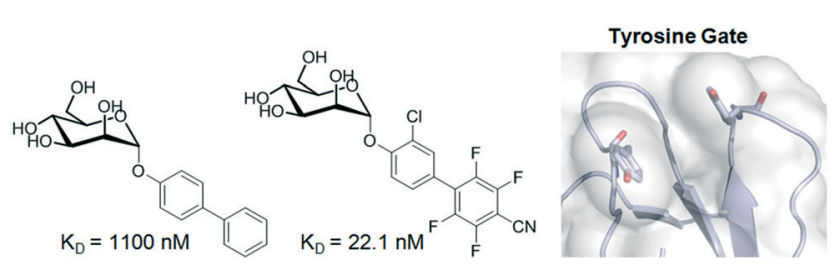

Fig. 4 Mannoside inhibitors of FimH displaying aromatic aglycones. 
respectively, and these examples demonstrate the success of the rationally designed driven approach applied to the discovery of selectin ligands. Selectins are cell surface lectins that bind to sialyl Lewis ${ }^{x}\left(\operatorname{sLe}^{\mathrm{x}}\right)$ antigens, mediate cell adhesion and play a key role in inflammatory processes (Fig. 5).

The discovery of new potent inhibitors is an active area of research. Ernst and co-workers used an NMR-guided fragment screening for designing $\mathrm{nM}$ affinity E-selectin inhibitors based on the attachment of the $\operatorname{sLe}^{\mathrm{x}}$ scaffold, which binds to the primary binding site, to a second site ligand. ${ }^{52}$ Additional strategies based on the use of glycopolymers with a multivalent presentation of $\mathrm{sLe}^{\mathrm{x}}$ or the single sugars Fuc, Gal, or Neu5Ac have also provided very promising results for inhibiting E-, P- and L-selectins. ${ }^{53}$ Other lectins such as DCSIGN, Siglecs and galectins, with important functions in inflammation or immune system activation, have also been considered as important targets. Sialic acid sugars, working as ligands of the immunosuppressive sialic acid binding immunoglobulin-like (Siglec) lectins, are emerging as important regulators of the immune system. Aberrant sialic acidSiglec interactions have been associated with multiple diseases including autoimmunity, infection, inflammation, aging or cancer. Therefore, glycomimetics targeting Siglecs have been pursued, especially for Siglec-2 (also called CD22). ${ }^{54}$ Sialoside mimetics carrying modifications on C-2, C-4, C-5 and C-9 of the sialic acid molecule were firstly envisaged, but later multiple site modifications led to more potent inhibitors. ${ }^{55}$ However, most of these glycomimetics do not have enough avidity to compete with natural glycoprotein ligands, ${ }^{56}$ and thus, multivalent presentation on polymers or nanoparticles provided more successful results. ${ }^{57}$ Interestingly, Paulson and co-workers have designed Siglec ligands based on di- and trivalent natural $\mathrm{N}$-glycan scaffolds which showed low nM/high pM avidity and were capable of being

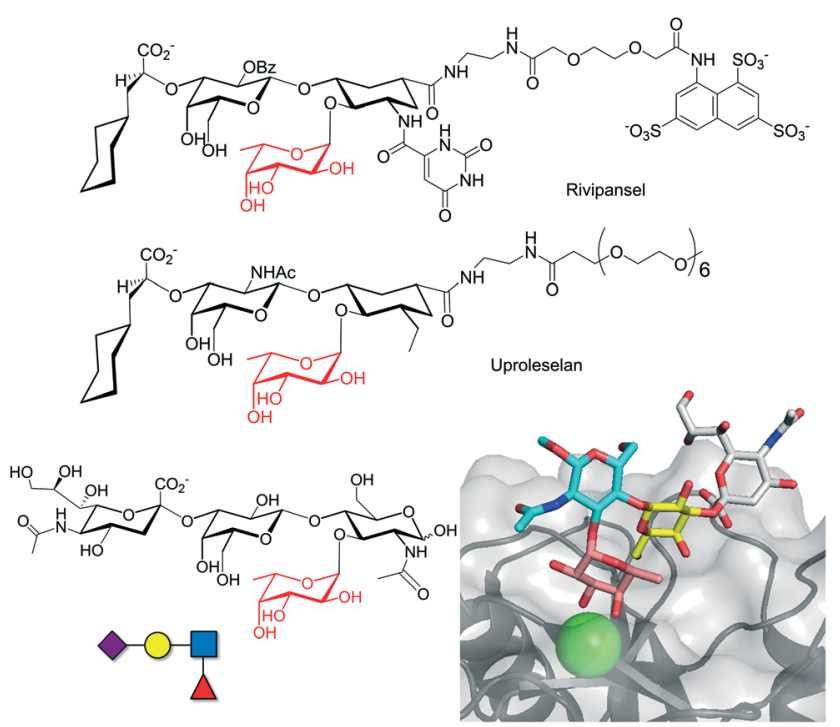

Fig. 5 Chemical structure of selectin inhibitors rivipansel and uproleselan. The chemical structure of $s \mathrm{Le}^{\mathrm{x}}$ antigen and the crystal structure of the interaction with selectin are depicted at the bottom (pdb 1G1T). endocytosed by CD22 on B lymphoma cells (Fig. 6) ${ }^{58}$ Feasibly, the individual branches of the chemically modified $\mathrm{N}$-glycans interact simultaneously with multiple CD22 receptors, increasing the binding affinity.

Single protein-carbohydrate interactions are usually weak and therefore chemical strategies must be applied to enhance the efficacy of glycomimetics. This is the case of the interaction between DC-SIGN and its natural ligands. DC-SIGN is a human C-type lectin receptor (CLR) located on the surface of dendritic cells that recognizes Lewis-type and high-mannose antigens. DC-SIGN introduces tolerance against self-antigens but also recognizes antigens from numerous pathogens (HIV, Ebola), a process that initiates an immune response or results in propagation and escape from the immune system. The structural features of the binding between natural sugars, including the blood type antigens and DC-SIGN, have been explored ${ }^{59}$ and revealed that the development of highaffinity ligands towards DC-SIGN has to overcome several drawbacks: the low affinity of the monovalent binding events, usually in the $\mathrm{mM}$ range, and the cross-reactivity among CLRs. Hence, considerable efforts have been made to develop high-affinity and selective glycomimetics. Indeed, approaches based on targeting extended binding sites have been investigated recently so as to improve the binding affinity. Although the strategy has not been applied yet to the design of potent DC-SIGN inhibitors, a library of 986 fragments has been screened using SPR, and five unknown secondary binding sites were validated using ${ }^{1} \mathrm{H}^{15} \mathrm{~N}$ HSQC NMR spectroscopy. ${ }^{60}$ Interestingly, the understanding of key binding structural features was successfully exploited for designing highly specific glycomimetics for DC-SIGN. ${ }^{61}$ The rational modification of first-generation glycomimetics based on dimannosides provided $\mu \mathrm{M}$ affinity inhibitors that specifically recognize DCSIGN vs. langerin, a similar CLR. Structural studies indicated that the introduction of a positive group on position C6 of the interacting sugar would reduce the affinity for langerin, since the stabilizing contacts with $\mathrm{K} 313$ on the binding site
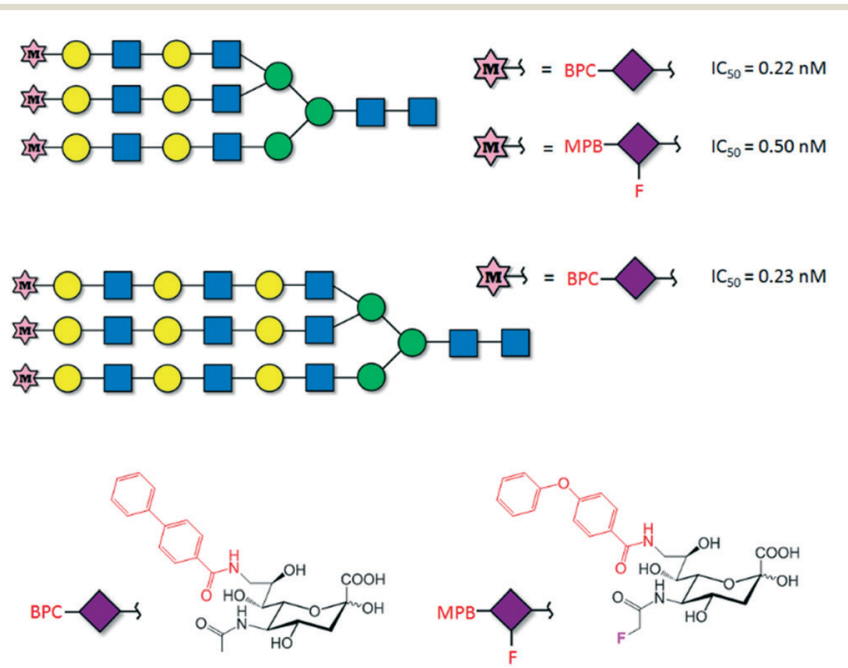

Fig. 6 Trivalent modified $N$-glycans described as $\mathrm{pM}$ inhibitors of Siglec-2. 
of the protein would be abolished. In fact, the introduction of a positively charged amino group in this position enhanced the affinity and selectivity towards DC-SIGN (Fig. 7A).

Notably, the structure of this compound is still far from that of an ideal drug-like molecule. Indeed, the affinity should be much more increased. The structurally open and waterexposed binding domain of DC-SIGN has hampered the development of potent glycomimetics and in fact, multivalency has been resorted to in order to increase the binding affinity (Fig. 7B). ${ }^{62}$ Recently, quantum dots surrounded by a dense array of mono- and disaccharides have been used as probes to gain insights into the binding mode of these multivalent interactions. ${ }^{63}$ Galectins, which comprise a large family of $\beta$-Dgalactoside-binding lectins, are also involved in many biological functions with important implications in cancer progression, inflammation, immune responses, fibrosis and heart diseases. ${ }^{64}$ In fact, the blockage of galectins by high-potency glycomimetics is being pursued as a therapeutic strategy ${ }^{65}$ and several related clinical trials are currently ongoing. ${ }^{66,67} \mathrm{~A}$ huge effort has been made on the synthesis of mono- and multivalent glycomimetics ${ }^{68}$ allowing access to promising galectin ligands. ${ }^{69}$ In addition, the structural binding features of galectins have been deeply investigated. We have recently demonstrated how ligand flexibility modulates the thermodynamics and kinetics of the protein-sugar binding process. ${ }^{70}$ Particularly, we found that histo blood group antigens, which are quite rigid, bind to human galectin- 3 with improved affinity due to their more favourable entropy of binding. Concerning this issue, a TF-mimetic with rather restricted conformational flexibility that efficiently binds to galectin-3 with a significant gain on the binding entropy has been re-
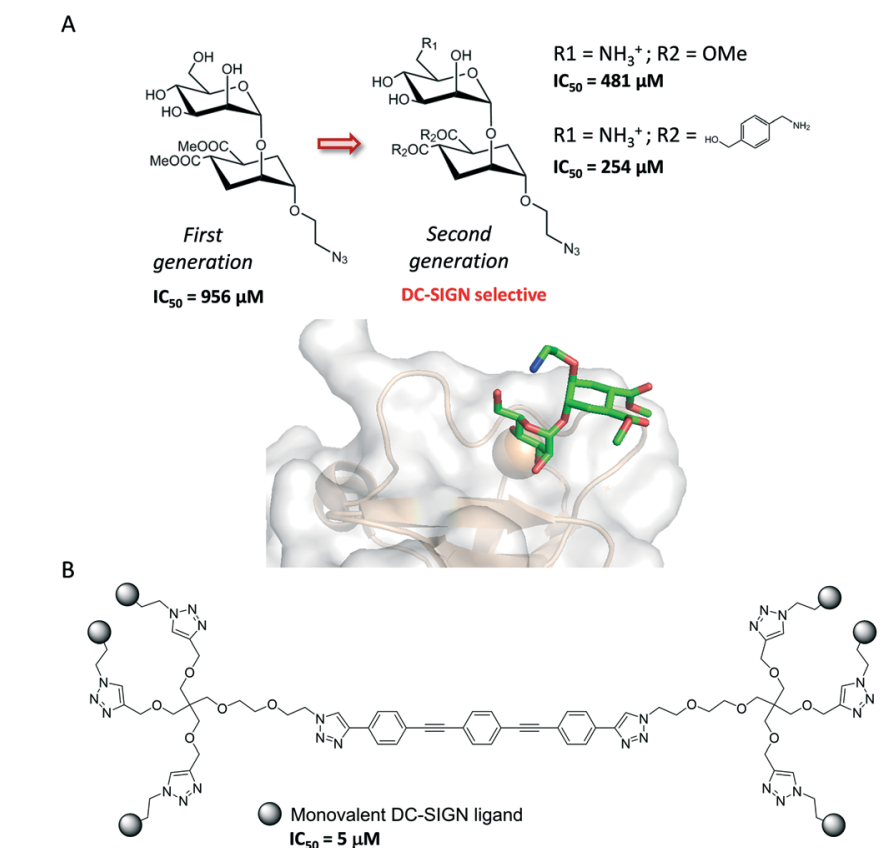

Fig. 7 (A) First- and second-generation DC-SIGN glycomimetics. The X-ray crystal structure of DC-SIGN bound to a second-generation glycomimetic is also represented (pdb 2XR5). (B) DC-SIGN multivalent ligand.

cently reported. ${ }^{71}$ Moreover, recent neutron crystallography studies of galectin-3 provided a detailed view of the $\mathrm{H}$-bonding network in the binding site of the protein. ${ }^{72}$ In particular, for galectin-3, the introduction of aromatic groups on the galactose C3 position of lactose, which established additional favourable cation $-\pi$ interactions with the protein, provided potent compounds. ${ }^{73}$ Moreover, studies with aromatic thiodigalactoside derivatives, with improved hydrolytic stability, yielded a low nanomolar inhibitor, ${ }^{74}$ TD139, ${ }^{75}$ which has been approved by the US Food and Drug Administration for the treatment of idiopathic pulmonary fibrosis. Subsequent structurally driven tuning of these molecules provided selective and potent $\mathrm{nM}$ inhibitors. ${ }^{76-78}$ The introduction of highly fluorinated aryltriazole groups on C3 favoured the interactions with the protein, reaching $K_{\mathrm{D}}$ values under 1-2 nM. In fact, this strategy has recently led to the development of aminopyrimidine-galactose hybrids with enhanced selectivity (>300-fold) towards galectin-3 over galectin- $1 .^{79}$ Similarly, the use of asymmetrical thiodigalactosides with C3-aryltriazolyl and O3-coumaryl groups has also led to high-affinity and selective galectin-3 inhibitors (Scheme 2). ${ }^{80}$

\section{Therapeutic glycopeptides}

Glycopeptide antibiotics (GPAs) such as vancomycin, teicoplanin, bleomycin and ristocetin were discovered a long time ago. However, more than $\mathbf{5 0}$ years after it was first introduced, vancomycin still constitutes a standard therapy against serious Gram-positive infections. In fact, the development of new antibiotic glycopeptides is still a current area of research. ${ }^{81}$ The general mechanism of action of glycopeptides such as vancomycin entails the binding to lipid II inhibiting the synthesis of peptidoglycans, a vital structural component of the bacterial cell wall. Although the sugar moiety does not participate in the direct contacts between vancomycin and lipid II, it plays a key role in the back-to-back dimerization of vancomycin that increases its lipid II binding affinity. ${ }^{82}$ Moreover, it has been suggested that the sugar residue provides steric hindrance and limits the conformational flexibility of the vancomycin molecule, driving it toward lipid II binding. ${ }^{83}$ Indeed, peptide or protein glycosylation exponentially expands the structure and biological functions of the

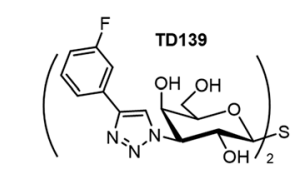

$\mathrm{K}_{\mathrm{D}}=68 \mathrm{nM}$

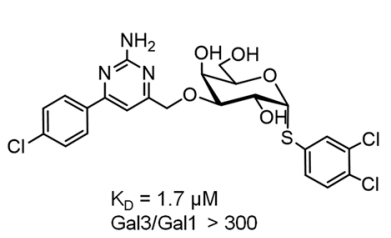

Scheme 2 High-affinity and selective thiodigalactoside glycomimetics of galectin-3. 
corresponding glycoconjugate. Factors such as the shape of the interacting glycopeptide or glycoprotein, the glycan density or additional carbohydrate-independent interactions modulate their solubility, stability and molecular recognition. ${ }^{84}$ However, the complexity and heterogeneity of the glycosylation process in natively expressed glycoproteins has hampered the complete understanding of those effects modulating their biological functions. Consequently, the synthetic preparation of homogeneous glycopeptides and glycoproteins has been pursued and allows extension of the overview beyond the "elemental" sugar-protein recognition phenomenon. In fact, synthetic glycopeptides also known as neoglycopeptides, capable of imitating the multivalent display of carbohydrates at the cell surface, have become an important objective as therapeutic compounds, and several reports appeared in the past years about targeting medically relevant lectins. ${ }^{85}$ Glycopeptide dendrimers, ${ }^{86}$ glycopeptide nanoparticles $^{87}$ or glycopolyproline scaffolds ${ }^{88}$ have been successfully designed to enhance lectin avidity.

HIV glycopeptide antigens. Synthetic glycopeptides mimicking natural HIV envelope glycoproteins have also been envisaged as anti-HIV therapy. Viral envelope glycoproteins at the surface of several viruses are targets for virus neutralization. These proteins, such as gp120 in HIV-1, are decorated with high-mannose-type glycans, which are the first structures to be encountered by the host immune system. While these $\mathrm{N}$-glycans are recognized as self-antigens and help to evade neutralization, much more potent antigenic responses can be obtained targeting both internal glycans and the protein surface. Hence, mimicking glycopeptides can be envisaged as a therapeutic strategy to elicit a broad antibody response. This approach was used by Wang and co-workers for the design and synthesis of glycopeptides which induced immune response against gp120. ${ }^{89}$ The minimal binding epitope was determined by analyzing the antibody binding affinity in a panel of V3 glycopeptides chemoenzymatically synthesized. The study indicated that a 33-mer V3 glycopeptide carrying a highmannose $N$-glycan at the N332 site is highly immunogenic (Fig. 8). Later studies with synthetic V3 N334 glycopeptides,

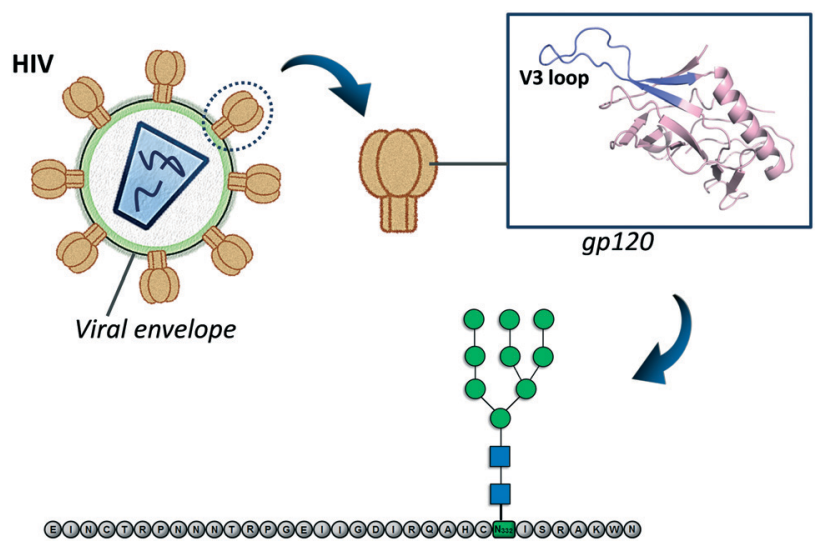

Fig. 8 Schematic representation of the employed approach to design anti-HIV immunogenic glycopeptides. including a mutation found in HIV isolates, showed its immunogenicity against gp120 and gp140 envelope glycoproteins. ${ }^{90}$ Also, a similar approach using modified envelope trimers has recently permitted the design of a novel immunogen (RC1) that efficiently stimulates the production of broadly neutralizing antibodies (bNAbs) by B cells. ${ }^{91}$ The RC1 architecture includes the key deletion of the N156 glycosylation site that gives rise to some structural changes without affecting its affinity.

Mucin glycopeptide antigens. The transmembrane mucin protein MUC1, which is overexpressed in many prevalent cancers, has also generated a lot of interest in the past recent years as a promising target. MUC1 is densely glycosylated in normal cells, but it is aberrantly glycosylated in tumourrelated cells presenting truncated glycan antigens (Tn, $\alpha-O$ GalNAc-Ser/Thr; T, $\alpha-O-G a l \beta 1-3 G a l N A c-S e r / T h r)$, and premature sialylation (sialyl-Tn and sialyl-T). Thus, specific antigens are exposed to the immune system, such as the peptide backbone or TACAs (tumor associated carbohydrate antigens), making them an attractive target for cancer immunotherapy (Fig. 9A). Over the past years, NMR, X-ray and molecular modelling-based studies have allowed building up a structure-guided approach for the design of vaccines. ${ }^{92}$ The combination of STD-NMR experiments with microarray binding experiments allowed the description of the epitope specificity of monoclonal antibodies against MUC1 and anti-Tn MUC1. The study pinpointed how the amino acid sequence and the sugar moiety are key factors modulating the binding to the antibodies. ${ }^{93}$ In 2015, Corzana and co-workers reported a detailed structural study regarding binding differences between $\alpha$-O-GalNAc-Ser and -Thr MUC1-like glycopeptides. ${ }^{94}$ X-ray crystals with SM3, an anti-MUC1 antibody, revealed that the glycosidic linkage of the bound Tn-Ser antigen and the

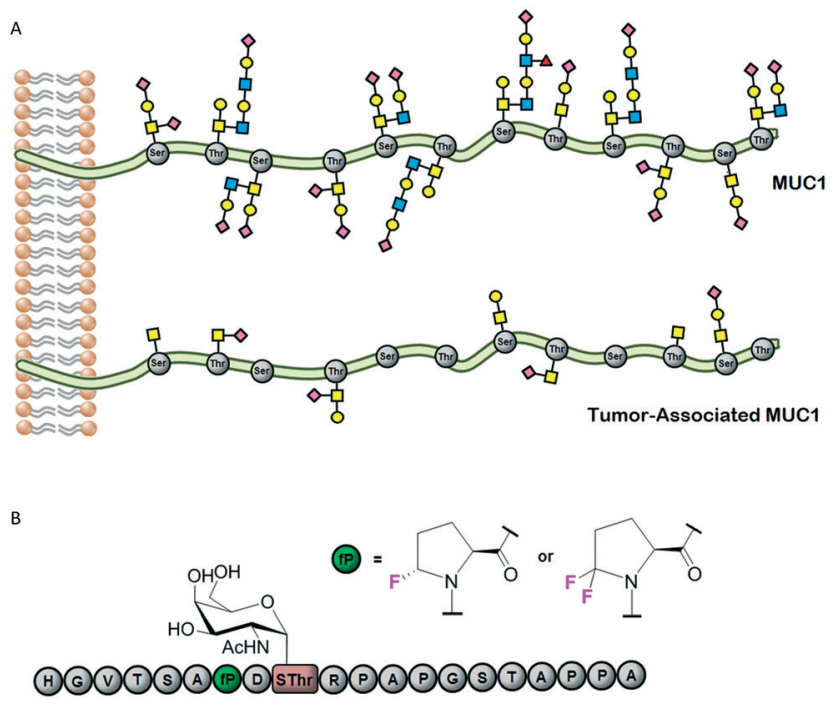

Fig. 9 (A) Model of normal densely glycosylated MUC1 and tumorassociated (TA) MUC1 with truncated glycosylation. (B) MUC1 synthetic glycopeptide bearing modifications at the peptide backbone and at the glycosidic linkage. 
Tn-Thr analogue featured different conformations, which finally impacts on their binding affinities. The Tn-Thr antigen, which showed higher affinity, displayed quite restricted conformational flexibility and mainly populates a single conformation both in solution and in the bound state. In contrast, the low-affinity Tn-Ser antigen is more flexible and exhibits different conformations around the glycosidic linkage. The distinct conformational features of both -Ser and -Thr antigens were deeply analysed and the key role of water molecules was elucidated. ${ }^{95}$ The study of these glycopeptides in solution and in the gas phase demonstrated the existence of a water pocket between the sugar moiety and the peptide backbone in the Tn-Thr antigen. GalNAc displayed a perpendicular arrangement with respect to the amino acid chain and allowed the accommodation of a water molecule, with important implications for the receptor binding. These insights were essential, since the use of glycopeptides able to imitate the conformational behaviour of cancer-associated MUC1 glycopeptides must be advantageous for the design of potent vaccines. ${ }^{96}$ The enhanced potency of 2,3-sialyl-T antigen based vaccines was also attributed to the improved turn-type conformation of the glycopeptide bearing this specific carbohydrate epitope. ${ }^{97}$ Interestingly, the $\mathrm{O} / \mathrm{S}$ or $\mathrm{O} / \mathrm{Se}$ substitution at the glycosidic linkage of MUC1 glycopeptides increases the affinity of the corresponding mimetic antigens. ${ }^{98}$ The presence of $\mathrm{S}$ and Se instead of an $\mathrm{O}$ atom increases the distance between the sugar moiety and the peptide backbone and allows the peptide to acquire a folded conformation, which is the optimum for binding to the antibody. Unnatural modifications on the peptide backbone were also successfully introduced in Tn-Thr antigens and improved the binding affinity. The substitution of proline by 4-fluoroproline or 4,4-difluoroproline at the most immunogenic natural peptide sequence of MUC1 (APDTRP), which strengthens the $\mathrm{CH}-\pi$ interactions with the antibody, provided potent non-natural antigens (Fig. 9B). ${ }^{99}$

The use of unnatural glycopeptides not only improves resistance against enzymatic degradation, but also overcomes cancer immune escape mechanisms. Indeed, when the $S$-glycoside mimetic carrying a fluoroproline was conjugated to gold nanoparticles and administered to mice, it provided a significant immune response, eliciting antibodies against cancer-related natural MUC1 antigens. The combination with immunostimulants is required for the activation of the T-celldependent pathways and the production of high-affinity IgG antibodies. Similarly, conjugation to carrier proteins, such as tetanus toxoid, bovine serum albumin $^{100}$ or bacteriophages, ${ }^{101}$ delivers potent MUC1 glycopeptide vaccines that selectively target tumour-associated MUC1 on tumour cells and not those on normal epithelial cells.

\section{Carbohydrate-based vaccines}

Carbohydrates with differentiating glycosylation patterns of pathogens or malignant host cells could be used as antigens for vaccine development. ${ }^{102}$ However, glycans in general are poorly immunogenic and unable to elicit a T-cell memory re- sponse. As a unique exception, polysaccharides with alternating positive and negative charges present at the surface of some Gram-positive bacteria are able to activate $T$ cells. ${ }^{103}$ Apart from this, vaccine development is usually achieved by conjugation of glycan antigens to appropriate carriers such as proteins, peptides or nanoparticles. In fact, chemical ligation has an impact on the vaccine efficiency and different methods have been developed. ${ }^{104}$ As described in the previous section, tumor-associated carbohydrate antigens represent specific targets for cancer immunotherapy, and vaccine design based on the synthetic modification of natural TACAs has provided promising results showing potent responses with reduced immunotolerance. ${ }^{105}$ Conjugates carrying bacterial glycans have also been extensively employed for vaccine preparation and the topic has been recently reviewed. ${ }^{106}$ Initially, the polysaccharide coats and major virulence factors of bacteria were isolated from natural sources, and then chemically conjugated to carrier proteins. Although these vaccination agents were capable of eliciting a T-cell-dependent immune response, the heterogeneity of the samples complicated the manufacturing and introduced undesirable side effects. More recently, the progress in carbohydrate chemistry and methods to determine the immunogenic glycan epitopes ${ }^{107}$ has permitted the development of rationally designed antibacterial and antifungal vaccines. However, bacterial pathogens such as Haemophilus influenza type b (Hib), Neisseria meningitidis, and Streptococcus pneumoniae continue to cause deadly diseases and the design of safe and highly efficacious vaccines is still an active area of research. For instance, Prevnar13 and Synflorix are currently employed pneumococcal vaccines, though they only cover 13 and 10, respectively, of more than 90 existing serotypes and consequently fail to offer a wide coverage. In this regard, Seeberger and co-workers have recently shown that glycoconjugates containing oligosaccharides of different $S$. pneumoniae serotypes can be coformulated or used in combination with marketed vaccines to generate a multivalent vaccine which induces a strong antibody response. ${ }^{108}$ Other novel approaches such as the use of outer membrane vesicles ${ }^{109}$ or TL4 ligands as carriers ${ }^{110}$ are being developed. Generally, such factors including the glycan epitope, the carrier protein, the chemical ligation of the sugar part or the activation mechanism of the immune system make it difficult to rationalize the response to vaccines, and thus, vaccine design results in a very challenging task. Interestingly, it has been described that the polysaccharide structure influences the antigen processing and in turn the mechanism underlying the adaptive immune response. ${ }^{111}$

\section{Glycoproteins and therapeutic applications}

The application of proteins as therapeutics in the pharmaceutical field has been incredibly expanded over the past years, proteins being one of the actual best-selling products for the treatment of a wide range of diseases and pathologies. In this regard, a great percentage of these proteins habitually display post-translational modifications (PTMs), and glycan 
attachment is one of the most prominent structural changes. More than half of the commercially available therapeutic proteins are glycoproteins, which are obtained through molecular biology protocols using living cell systems. Since the glycan profile is essentially heterogeneous the recent research still pursues the development and application of robust protocols to analyse the glycan profile of both commercial and potentially therapeutic glycoproteins, ${ }^{112-114}$ trying to better understand how those different glycoforms affect the product quality in terms of effectiveness, stability, pharmacokinetics and toxicity. ${ }^{115,116}$ Usually, the carbohydrate content of intact glycoproteins is directly assessed by chromatographic separation coupled to mass spectrometry detection. Recently, a novel workflow has been designed which uses relatively simple LC or LC/MS methods to characterize complex glycosylated proteins and antibodies at different levels (intact glycoprotein, fragments cleaved by different proteases, released glycans). ${ }^{117}$ Even so, minor changes in the $N$-glycosylation pattern are difficult to detect in the extracted ion chromatograms. In this regard, Planinc et al. have proposed an interesting approach oriented to combine the sensitivity of MS detection devices with subsequent principal component analysis (PCA) and classification through soft independent modelling by class analogy (SIMCA) that can be applied to the evaluation of previously released glycans via enzymatic cleavage. ${ }^{118}$ Lately, a new and robust capillary electrophoresis-based method coupled to ESI-MS has permitted the determination of the glycan content of diverse known mAbs, highlighting the reproducibility and the accuracy of the results by comparison with a HILIC-based reference method. ${ }^{119}$ Additionally, the applicability of lectin microarrays ${ }^{120}$ to screen the glycans of therapeutic glycoproteins, especially monoclonal antibodies, has also been highlighted. ${ }^{121}$

Monoclonal antibodies. Typically, monoclonal antibodies are $\mathrm{N}$-glycosylated at the residue Asn297, located on the $\mathrm{CH} 2$ domain of each heavy chain, and the type of structural sugars may influence critical aspects on the mAb function. ${ }^{122}$ Indeed, glycan heterogeneity accounts for the already known asymmetrical binding of the Fc segment to the Fc receptors. Moreover, the presence or absence of specific carbohydrates may be either positive or negative for the engagement of the corresponding Fcy receptors (Fc $\gamma \mathrm{R}),{ }^{123}$ and consequently, both modifications could be exploited to improve the safety and efficacy of potentially commercial mAbs (Fig. 10).

For instance, reported evidence already exists about the effects of non-reducing galactose and fucose terminal residues on the immune effector functions of antibodies. ${ }^{125}$ Recently, an antibody constituted by a non-glycosylated F8-based diabody has been engineered, in which each F8 unit is fused via the C-terminus to a glycosylated interleukin-9 (IL9). ${ }^{126}$ With this system, Venetz and co-workers demonstrated that variations in the $N$-linked glycans deeply changed the efficiency of the F8 fragment to target the tumor cells. By quantitative distribution analyses, they interestingly found a positive correlation between the level of sialylation in IL9 $\mathrm{N}$-glycans and the capability of the F8 moiety to specifically

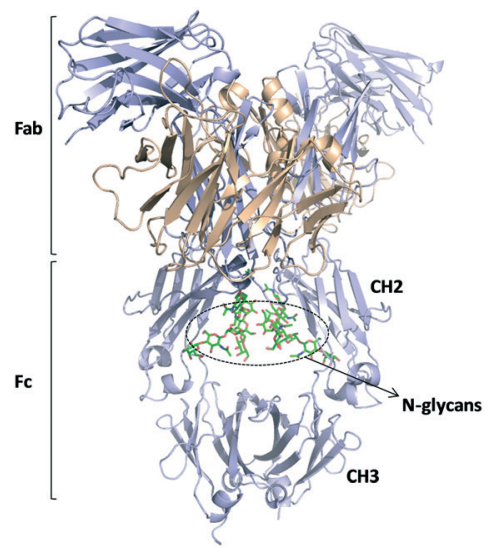

Fig. 10 Schematic representation of an IgG1 antibody structure (pdb $1 \mathrm{HZH}){ }^{124} \mathrm{Fab}$ and Fc regions are indicated and the glycans present in the $\mathrm{CH} 2$ domains are highlighted.

bind the spliced extradomain A (EDA) of fibronectin. Similarly, the importance of controlling microheterogeneity in the production of mAbs with therapeutic purposes has been underlined. Indeed, it has been proposed that discrepancies in efficiency and safety among mAbs could be explained by differences in the surface charge of each glycoform as a consequence of the existing heterogeneous glycan environments. $^{127}$

Preparation of homogenous glycoproteins. The enormous importance of glycoproteins as therapeutics has led a lot of research groups to keep improving existing protocols to express a given glycoprotein with the desired glycan profile. Although non-mammalian hosts are available to be used as well, like insect or yeast cells, ${ }^{128,129}$ Chinese hamster ovary (CHO) cells are habitually the chosen expression systems for preparing glycosylated proteins. However, glycan remodeling is often mandatory in most cases to remove some non-human epitopes that can lead to undesired side effects during the therapy $^{130}$ and to achieve glycan homogeneity. In general terms, enzymatic glycoengineering is carried out by means of glycosidases, glycosyltransferases and other enzymes to add or remove certain monosaccharides or larger fragments (Fig. 11A). ${ }^{131,132}$ Notably, endo- $\beta$ - $N$-acetylglucosaminidases (ENGases) are emerging as highly flexible and adaptable biocatalysts to afford homogeneous $\mathrm{N}$-linked glycoproteins following a divergent biosynthetic scheme. ${ }^{133,134}$ The glycosylated protein is normally produced by cell expression and the incorporated glycans are later cleaved at the glycosidic linkage between the first and the second GlcNAc moieties (the inner chitobiose segment). Then, ENGases can be conversely employed to catalyse the insertion of a custom oligosaccharide chain into a single GlcNAc residue (Fig. 11B). ${ }^{132}$

Besides enzyme-based remodeling, special engineered yeast strains with altered biosynthetic routes are likewise used to afford mammalian-like glycans. ${ }^{135}$ A modified yeast strain has been prepared by disparity mutagenesis, which is glycosylation-deficient and exclusively produces highmannose-type $N$-glycans (Man9). ${ }^{136}$ An alternative strategy for 


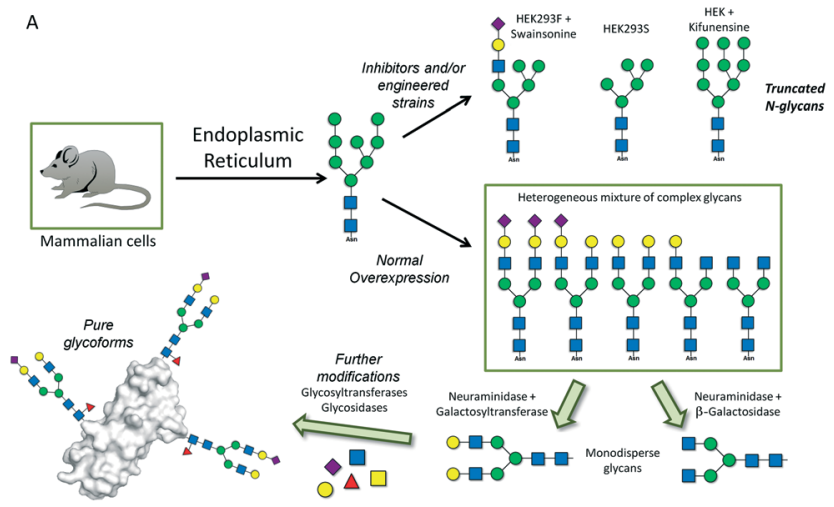

B

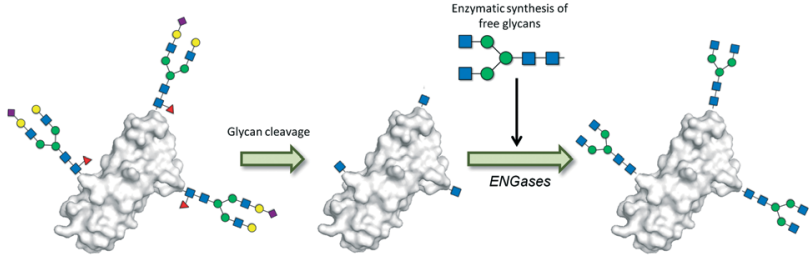

Fig. 11 Biosynthetic approaches for the preparation of homogeneous glycoproteins. (A) Previous and post enzyme-based remodeling of the overexpressed glycoforms. (B) Cleavage and subsequent incorporation of the desired oligosaccharide chain.

glycoprotein preparation is total chemical synthesis or semisynthesis. Native chemical ligation (NCL) techniques allow the chemoselective linkage of peptidic fragments through coupling of a C-terminal thioester to an $\mathrm{N}$-terminal cysteine residue. ${ }^{137}$ This approach still has some important limitations, especially for quite long proteins that would require multiple ligations. The chemical lability of thioesters, also subjected to epimerization equilibria, and the low percentage of cysteine residues in protein sequences constitute the major drawbacks. Consequently, and given the complexity and variability of peptide fragments that may be needed, this area of research remains under study and optimization. The use of $\beta$-mercapto amino acid analogues instead of natural cysteines, and the utilization of peptide hydrazides, which are more stable, as substitutes for peptide thioesters are some of the alternatives that have been described so far. ${ }^{138}$

Commercial glycoproteins. The list of commercial glycoproteins with therapeutic applications is incredibly large and a high percentage of them are monoclonal antibodies. Some of them, like erythropoietin (EPO) and Herceptin (trastuzumab), are extensively used nowadays and remain part of multiple research projects aimed at expanding and improving their applicability and effectiveness. EPO has been used in the treatment of Alzheimer's disease due to its known neuroprotective effects in rodent models. A fusion antibody consisting of an EPO subunit attached to a chimeric monoclonal antibody targeting the transferrin receptor (TfRMAb) has been recently developed. ${ }^{139}$ With this design, the required EPO dosage to achieve effectiveness was successfully reduced, improving the penetration of this therapeutic mAb through the blood-brain barrier (BBB). Analogously, these neuroprotective properties of EPO also have promising applications for the treatment of traumatic brain injuries (TBIs) in young patients. Recently, data from published randomized controlled trials (RCTs) about the effectiveness of EPO for this purpose have been described. ${ }^{140}$ Although the therapeutic effects in human patients with TBI have remained unclear over the past years, it could be demonstrated, from a global perspective, that EPO treatment is not only safe for patients but it also noticeably reduces the mortality rate of these patients. In colon cancer, EPO has been reported to help in reducing the growth rate of malignant cells when it is simultaneously administered with LFM-A13, the inhibitor used to target Bruton's tyrosine kinase (BTK), which is overexpressed in this type of cancer. $^{141}$ Herceptin, commercially known as trastuzumab, is a glycosylated antibody used to treat earlystage breast cancers. Rasaneh et al. have recently proposed a novel method to increase the therapeutic efficiency of Herceptin by linking this antibody to the surface of iron oxide nanoparticles with magnetic properties. ${ }^{142}$ The results were promising in mice, showing that the accumulation of these Herceptin-loaded nanoparticles at the tumour tissues was efficiently achieved in the presence of a magnetic field and led to a slower tumour growth rate compared with Herceptin alone. Similarly, conjugation of Herceptin to a macromolecular scaffold has also been exploited to enhance the therapeutic effect of cisplatin for tumour treatment. ${ }^{143}$ Making use of a functionalized polyamidoamine dendrimer (PAMAM) bearing both cisplatin and Herceptin, better therapeutic properties (lower $\mathrm{IC}_{50}$ values, enhanced apoptosis) were observed in ovarian cancer cell lines in comparison with free cisplatin or dendrimers carrying cisplatin in the absence of Herceptin.

\section{Conclusions}

In the past years, many contributions have demonstrated that the exploitation of carbohydrates in medicinal chemistry opens a broad spectrum of therapeutic possibilities. Despite the technical challenges associated with the intrinsic complexity of glycans, tailor-made small glycomimetics have been designed for blocking specific carbohydrate-lectin interactions. The success of rationally driven approaches for the development of new drugs is still to be widely demonstrated, although it is clearly improving. In fact, several glycomimetics are already in clinical trials. Nevertheless, more specific targets for glycomimetics still have to be uncovered. The enormous progress in synthetic strategies, analytical tools and high-resolution biophysical techniques has allowed advances in the study of complex glycosylated structures, including glycoproteins. Dendrimers, nanoparticles and other polyvalent structures have been introduced as a strategy to increase avidity, not to mention the therapeutic potential of specifically designed glycopeptides. The development of glycopeptide-based vaccines aimed to fight diseases such as cancer or HIV is an active area of research. Similarly, potent anti-bacterial vaccines have been developed. In this regard, more attention should be paid to the mechanisms underlying 
the immune response, where the role of glycan epitopes remains not fully understood. However, the awareness of the key role of glycans also on the antibody effectiveness, stability, pharmacokinetics and toxicity has broken the limits of their therapeutic applications. Definitely, progress in glycoprotein expression and their structural analysis is beginning to overcome the challenge derived from the complexity of large glycoconjugates. Furthermore, aspects directed to the study of the cell-surface microenvironment effects are also being addressed. Surely, the increasing understanding of all aspects of glycoscience will allow the development of novel and more effective therapies.

\section{Conflicts of interest}

There are no conflicts to declare.

\section{Acknowledgements}

We thank the European Research Council for financial support (ERC-2017-AdG, project number 788143-RECGLYCANMR). We also thank Instituto de Salud Carlos III of Spain, ISCIII (grant PRB3 IPT17/0019 to A. G.) and Agencia Estatal Investigación of Spain, AEI (grants CTQ2015-64597-C2-1-P and RTI2018-094751-B-C21 and the Severo Ochoa Excellence Accreditation SEV-2016-0644).

\section{Notes and references}

1 R. D. Cummings and M. E. Etzler, Essentials of Glycobiology, ed. A. Varki, R. D. Cummings, J. D. Esko, H. H. Freeze, P. Stanley, C. R. Bertozzi, G. W. Hart and M. E. Etzler, Cold Spring Harbor (NY): Cold Spring Harbor Laboratory Press, New York, 2nd edn, 2009, ch. 6.

2 A. Varki, Glycobiology, 2017, 27, 3-49.

3 C. Reily, T. J. Stewart, M. B. Renfrow and J. Novak, Nat. Rev. Nephrol., 2019, 15, 346-366.

4 H. J. Joshi, Y. Narimatsu, K. T. Schjoldager, H. L. P. Tytgat, M. Aebi, H. Clausen and A. Halim, Cell, 2018, 172, 632-632. e2.

5 F. Schwarz and M. Aebi, Curr. Opin. Struct. Biol., 2011, 21, 576-582.

6 J. Nilsson, A. Halim, A. Grahn and G. Larson, Glycoconjugate J., 2013, 30, 119-136.

7 (a) A. V. Everest-Dass, E. S. X. Moh, C. Ashwood, A. M. M. Shathili and N. H. Packer, Expert Rev. Proteomics, 2018, 15, 165; (b) M. J. Kailemia, G. Xu, M. Wong, Q. Li, E. Goonatilleke, F. Leon and C. B. Lebrilla, Anal. Chem., 2018, 90, 208.

8 L. Krasnova and C.-H. Wong, J. Am. Chem. Soc., 2019, 1411, 3735-3754.

9 T. M. Puvirajesinghe and J. E. Turnbull, Microarrays, 2016, 5, 3.

10 J. Agirre, G. J. Davies, K. S. Wilson and K. D. Cowtan, Curr. Opin. Struct. Biol., 2017, 44, 39-47.

11 (a) D. Sirohi, Z. Chen, L. Sun, T. Klose, T. C. Pierson, M. G. Rossmann and R. J. Kuhn, Science, 2016, 352, 467-470; (b)
H. B. Gristick, H. Wang and P. J. Bjorkman, Acta Crystallogr., Sect. D: Struct. Biol., 2017, 73, 822-828.

12 A. Ardá, H. Coelho, B. Fernández de Toro, S. Galante, A. Gimeno, A. Poveda, J. Sastre, L. Unione, P. Valverde, F. Javier Cañada and J. Jiménez-Barbero, Special Periodic Reports. Carbohydrate Chemistry, ed. A. P. Rauter, T. Lindhorst and Y. Queneau, RSC, 2017, ch. 2, vol. 42.

13 A. Ardá and J. Jiménez-Barbero, Chem. Commun., 2018, 54, 4761-4769.

14 A. Diniz, J. S. Dias, J. Jiménez-Barbero, F. Marcelo and E. J. Cabrita, Chem. - Eur. J., 2017, 23, 13213-13220.

15 S. C. Purcell and K. Godula, Interface Focus, 2019, 9, 20180080.

16 E. Luchinat and L. Banci, IUCrJ, 2017, 4, 108-118.

17 (a) A. Fernández-Tejada, F. J. Cañada and J. JiménezBarbero, ChemMedChem, 2015, 10, 1291-1295; (b) A. Fernández-Tejada, F. J. Cañada and J. Jiménez-Barbero, Chem. - Eur. J., 2015, 21, 10616-10628; (c) J. E. Hudak and C. R. Bertozzi, Chem. Biol., 2014, 21, 16-37; (d) S. Cecioni, A. Imberty and S. Vidal, Chem. Rev., 2015, 115, 525-561; (e) M. Dalziel, M. Crispin, C. N. Scanlan, N. Zitzmann and R. A. Dwek, Science, 2014, 343, 1235681; $(f)$ R. Hevey, Pharmaceuticals, 2019, 12, 55.

18 R. J. Linhardt, J. Med. Chem., 2003, 46, 2551-2564.

19 (a) M. Guerrini, D. Beccati, Z. Shriver, A. Naggi, K. Viswanathan, A. Bisio, I. Capila, J. C. Lansing, S. Guglieri, B. Fraser, A. Al-Hakim, N. S. Gunay, Z. Zhang, L. Robinson, L. Buhse, M. Nasr, J. Woodcock, R. Langer, G. Venkataraman, R. J. Linhardt, B. Casu, G. Torri and R. Sasisekharan, Nat. Biotechnol., 2008, 26, 669-675; (b) D. Keire, B. Mulloy, C. Chase, A. Al-Hakim, D. Cairatti, E. Gray, J. Hogwood, T. Morris, P. Mourao, M. D. Soares and A. Szajek, BioPharm Int., 2015, 28, 36-42.

20 S. Mohamed and D. R. Coombe, Pharmaceuticals, 2017, 10, 78.

21 J. M. Herbert, M. Petitou, J. C. Lormeau, R. Cariou, J. Necciari, H. N. Magnani, P. Zandberg, R. G. M. van Amsterdam, C. A. A. van Boeckel and D. G. Meuleman, Cardiovasc. Drug Rev., 1997, 15, 1-26.

22 (a) D. Fisher, B. Xing, J. Dill, H. Li, H. H. Hoang, Z. Z. Zhao, X. L. Yang, R. Bachoo, S. Cannon, F. M. Longo, M. Sheng, J. Silver and S. X. Li, J. Neurosci., 2011, 31, 14051-14066; (b) Y. J. Shen, A. P. Tenney, S. A. Busch, K. P. Horn, F. X. Cuascut, K. Liu, Z. G. He, J. Silver and J. G. Flanagan, Science, 2009, 326, 592-596; (c) C. H. Coles, Y. Shen, A. P. Tenney, C. Siebold, G. C. Sutton, W. Lu, J. T. Gallagher, E. Y. Jones, J. G. Flanagan and A. R. Aricescu, Science, 2011, 332, 484-488.

23 (a) Y. Ohtake and S. X. Li, Brain Res., 2015, 1619, 22-35; (b) A. W. Stoker, Semin. Cell Dev. Biol., 2015, 37, 90-97.

24 X. Dai, W. Liu, Q. Zhou, C. Cheng, C. Yang, S. Wang, M. Zhang, P. Tang, H. Song, D. Zhang and Y. Qin, J. Org. Chem., 2016, 81(1), 162-184.

25 U. Bhaskar, E. Sterner, A. M. Hickey, A. Onishi, F. Zhang, J. S. Dordick and R. J. Linhardt, Appl. Microbiol. Biotechnol., 2012, 93, 1-16. 
26 S. Dey, H. Lo and C. H. Wong, J. Am. Chem. Soc., 2019, 141, 10309-10314.

27 (a) S. U. Hansen, G. J. Miller, G. C. Jayson and J. M. Gardiner, Org. Lett., 2013, 15(1), 88-91; (b) S. U. Hansen, G. J. Miller, M. J. Cliff, G. C. Jayson and J. M. Gardiner, Chem. Sci., 2015, 6(11), 6158-6164.

28 (a) M. Baráth, S. U. Hansen, C. E. Dalton, G. C. Jayson, G. J. Miller and J. M. Gardiner, Molecules, 2015, 20(4), 6167-6180; (b) S. Dey and C. H. Wong, Chem. Sci., 2018, 9(32), 6685-6691.

29 C. Zong, A. Venot, O. Dhamale and G. J. Boons, Org. Lett., 2013, 15(2), 342-345.

30 S. U. Hansen, G. J. Miller, C. Cole, G. Rushton, E. Avizienyte, G. C. Jayson and J. M. Gardiner, Nat. Commun., 2013, 4, 2016.

31 X. Zhang, V. Pagadala, H. M. Jester, A. M. Lim, T. Q. Pham, A. P. Goulas, J. Liu and R. J. Linhardt, Chem. Sci., 2017, 8(12), 7932-7940.

32 M. S. Lord, B. Cheng, F. Tang, J. G. Lyons, J. RnjakKovacina and J. M. Whitelock, Metab. Eng., 2016, 38, 105-114.

33 B. E. Stopschinski, B. B. Holmes, G. M. Miller, V. A. Manon, J. Vaquer-Alicea, W. L. Prueitt, L. C. Hsieh-Wilson and M. I. Diamond, J. Biol. Chem., 2018, 293(27), 10826-10840.

34 (a) E. Avizienyte, C. L. Cole, G. Rushton, G. J. Miller, A. Bugatti, M. Presta, J. M. Gardiner and G. C. Jayson, PLoS One, 2016, 11(8), e0159739; (b) G. J. Miller, S. U. Hansen, E. Avizienyte, G. Rushton, C. L. Cole, G. C. Jayson and J. M. Gardiner, Chem. Sci., 2013, 4, 3218-3222.

35 G. C. Jayson, S. U. Hansen, G. J. Miller, C. L. Cole, G. Rushton, E. Avizienyte and J. M. Gardiner, Chem. Commun., 2015, 51(72), 13846-13849.

36 C. Zong, R. Huang, E. Condac, Y. Chiu, W. Xiao, X. Li, W. Lu, M. Ishahara, S. Wang, A. Ramiah, M. Stickney, P. Azadi, I. J. Amster, K. W. Moremen, L. Wang, J. S. Sharp and G. J. Boons, J. Am. Chem. Soc., 2016, 138(39), 13059-13067.

37 L. Unione, A. Gimeno, P. Valverde, I. Calloni, H. Coelho, S. Mirabella, A. Poveda, A. Ardá and J. Jimenez-Barbero, Curr. Med. Chem., 2017, 24, 4057-4080.

38 R. Sommer, S. Wagner, A. Varrot, C. M. Nycholat, A. Khaledi, S. Häussler, J. C. Paulson, A. Imberty and A. Titz, Chem. Sci., 2016, 7, 4990-5001.

39 S. Wang, L. Dupin, M. Noel, C. J. Carroux, L. Renaud, T. Gehin, A. Meyer, E. Souteyrand, J. J. Vasseur, G. Vergoten, Y. Chevolot, F. Morvana and S. Vidal, Chem. - Eur. J., 2016, 22, 11785-11794.

40 K. Buffet, I. Nierengarten, N. Galanos, E. Gillon, M. Holler, A. Imberty, S. E. Matthews, S. Vidal, S. P. Vincenta and J. F. Nierengarten, Chem. - Eur. J., 2016, 22, 2955-2963.

41 G. Michaud, R. Visini, M. Bergmann, G. Salerno, R. Bosco, E. Gillon, B. Richichi, C. Nativi, A. Imberty, A. Stocker, T. Darbre and J.-L. Reymond, Chem. Sci., 2016, 7, 166-182.

42 R. Sommer, D. Hauck, A. Varrot, S. Wagner, A. Audfray, A. Prestel, H. M. Mçller, A. Imberty and A. Titz, ChemistryOpen, 2015, 4, 756-767.
43 R. Sommer, S. Wagner, K. Rox, A. Varrot, D. Hauck, E.-C. Wamhoff, J. Schreiber, T. Ryckmans, T. Brunner, C. Rademacher, R. W. Hartmann, M. Brönstrup, A. Imberty and A. Titz, J. Am. Chem. Soc., 2018, 140, 2537-2545.

44 V. Denavit, D. Lainé, C. Bouzriba, E. Shanina, É. Gillon, S. Fortin, C. Rademacher, A. Imberty and D. Giguère, Chem. Eur. J., 2019, 25, 4478-4490.

45 S. Wagner, D. Hauck, M. Hoffmann, R. Sommer, I. Joachim, R. Müller, A. Imberty, A. Varrota and A. Titz, Angew. Chem., Int. Ed., 2017, 56, 16559-16564.

46 J. Bouckaert, J. Berglund, M. Schembri, E. De Genst, L. Cools, M. Wuhrer, C. S. Hung, J. Pinkner, R. Slattegard, A. Zavialov, D. Choudhury, S. Langermann, S. J. Hultgren, L. Wyns, P. Klemm, S. Oscarson, S. D. Knight and H. De Greve, Mol. Microbiol., 2005, 55, 441-455.

47 (a) S. Kleeb, L. Pang, K. Mayer, D. Eris, A. Sigl, R. C. Preston, P. Zihlmann, T. Sharpe, R. P. Jakob, D. Abgottspon, A. S. Hutter, M. Scharenberg, X. Jiang, G. Navarra, S. Rabbani, M. Smiesko, N. Ludin, J. Bezencon, O. Schwardt, T. Maiera and B. Ernst, J. Med. Chem., 2015, 58, 2221-2239; (b) C. Jarvis, Z. Han, V. Kalas, R. Klein, J. S. Pinkner, B. Ford, J. Binkley, C. K. Cusumano, Z. Cusumano, L. Mydock-McGrane, S. J. Hultgren and J. W. Janetka, ChemMedChem, 2016, 11, 367-373.

48 W. Schönemann, J. Cramer, T. Mühlethaler, B. Fiege, M. Silbermann, S. Rabbani, P. Dätwyler, P. Zihlmann, R. P. Jakob, C. P. Sager, M. Smieško, O. Schwardt, T. Maier and B. Ernst, ChemMedChem, 2019, 14, 749-757.

49 S. Kleeb, X. Jiang, P. Frei, A. Sigl, J. Bezencon, K. Bamberger, O. Schwardt and B. Ernst, J. Med. Chem., 2016, 59(7), 3163-3182.

50 C. P. Sager, B. Fiege, P. Zihlmann, R. Vannam, S. Rabbani, R. P. Jakob, R. C. Preston, A. Zalewski, T. Maier, M. W. Peczuh and B. Ernst, Chem. Sci., 2018, 9, 646-654.

51 P. Zihlmann, M. Silbermann, T. Sharpe, X. Jiang, T. Mühlethaler, R. P. Jakob, S. Rabbani, C. P. Sager, P. Frei, T. Maier and B. Ernst, Chem. - Eur. J., 2018, 24, 13049-13057.

52 J. Egger, C. Weckerle, B. Cutting, O. Schwardt, S. Rabbani, K. Lemme and B. Ernst, J. Am. Chem. Soc., 2013, 135, 9820-9828.

53 K. E. Moog, M. Barz, M. Bartneck, F. Beceren-Braun, N. Mohr, Z. Wu, L. Braun, J. Dernedde, E. A. Liehn, F. Tacke, T. Lammers, H. Kunz and R. Zentel, Angew. Chem., Int. Ed., 2016, 55, 1416-1421.

54 T. Angata, C. M. Nycholat and M. S. Macauley, Trends Pharmacol. Sci., 2015, 36, 645-660.

55 C. Büll, T. Heise, G. J. Adema and T. J. Boltje, Trends Biochem. Sci., 2016, 41, 519-531.

56 J. Ereño-Orbea, T. Sicard, H. Cui, M. T. Mazhab-Jafari, S. Benlekbir, A. Guarné, J. L. Rubinstein and J.-P. Julien, Nat. Commun., 2017, 8, 764.

57 H. Prescher, A. Schweizer, E. Kuhfeldt, L. Nitschke and R. Brossmer, ChemBioChem, 2017, 18, 1216-1225.

58 W. Peng and J. C. Paulson, J. Am. Chem. Soc., 2017, 139, 12450-12458. 
59 (a) H. Feinberg, R. Castelli, K. Drickamer, P. H. Seeberger and W. I. Weis, J. Biol. Chem., 2007, 282, 4202-4209; (b) A. Holla and A. Skerra, Protein Eng., Des. Sel., 2011, 24, 659-669; (c) K. Brzezicka, B. Echeverria, S. Serna, A. Van Diepen, C. H. Hooke and N.-C. Reichardt, ACS Chem. Biol., 2015, 10, 1290-1302; (d) K. Pederson, D. A. Mitchell and J. H. Prestegard, Biochemistry, 2014, 53, 5700-5709; (e) J. D. Martínez, P. Valverde, S. Delgado, C. Romanò, B. Linclau, N. C. Reichardt, S. Oscarson, A. Ardá, J. Jiménez-Barbero and F. J. Cañada, Molecules, 2019, 24, E2337; $(f)$ P. Valverde, S. Delgado, J. D. Martínez, J.-B. Vendeville, B. Linclau, J. Malassis, N. C. Reichardt, F. J. Cañada, J. Jiménez-Barbero and A. Ardá, ACS Chem. Biol., 2019, 14, 1660-1671.

60 J. Aretz, H. Baukmann, E. Shanina, J. Hanske, R. Wawrzinek, V. A. Zapolśkii, P. H. Seeberger, D. E. Kaufmann and C. Rademacher, Angew. Chem., Int. Ed., 2017, 56, 7292-7296.

61 V. Porkolab, E. Chabrol, N. Varga, S. Ordanini, I. Sutkevičiūtė, M. Thepau, M. J. Garcia-Jimenez, E. Girard, P. M. Nieto, A. Bernardi and F. Fieschi, ACS Chem. Biol., 2018, 13, 600 .

62 (a) B. Bertolotti, I. Sutkeviciute, M. Ambrosini, R. Ribeiro-Viana, J. Rojo, F. Fieschi, H. Dvořáková, M. Kašáková, K. Parkan, M. Hlaváčková, K. Nováková and J. Moravcová, Org. Biomol. Chem., 2017, 15, 3995; (b) S. Ordanini, N. Varga, V. Porkolab, M. Thépaut, L. Belvisi, A. Bertaglia, A. Palmioli, A. Berzi, D. Trabattoni, M. Clerici, F. Fieschi and A. Bernardi, Chem. Commun., 2015, 51, 3816; (c) A. Berzi, S. Ordanini, B. Joosten, D. Trabattoni, A. Cambi, A. Bernardi and M. Clerici, Sci. Rep., 2016, 6, 35373.

63 Y. Guo, I. Nehlmeier, E. Poole, C. Sakonsinsiri, N. Hondow, A. Brown, Q. Li, S. Li, J. Whitworth, Z. Li, A. Yu, R. Brydson, W. B. Turnbull, S. Pöhlmann and D. Zhou, J. Am. Chem. Soc., 2017, 139, 11833-11844.

64 L. Johannes, R. Jacob and H. Leffler, J. Cell Sci., 2018, 131, jcs208884.

65 R. P. M. Dings, M. C. Miller, R. J. Griffin and K. H. Mayo, Int. J. Mol. Sci., 2018, 19, 905.

66 A. Girard and J. L. Magnani, Trends Glycosci. Glycotechnol., 2018, 30, SE211-SE220.

67 H. Blanchard, X. Yu, P. M. Collins and K. Bum-Erdene, Expert Opin. Ther. Pat., 2014, 24, 1053-1065.

68 V. L. Campo, M. F. Marchiori, L. C. Rodrigues and M. DiasBaruffi, Glycoconjugate J., 2016, 3, 853-876.

69 D. Laaf, P. Bojarová, L. Elling and V. Kren, Trends Biotechnol., 2019, 37, 402-415.

70 A. Gimeno, S. Delgado, P. Valverde, S. Bertuzzi, M. A. Berbis, J. Echavarren, A. Lacetera, S. MartínSantamaria, A. Surolia, F. J. Cañada, J. JimenezBarbero and A. Ardá, Angew. Chem., Int. Ed., 2019, 58, 7268-7272.

71 S. Santarsia, A. S. Grosso, F. Trovão, J. Jiménez-Barbero, A. L. Carvalho, C. Nativi and F. Marcelo, ChemMedChem, 2018, 13, 2030-2036.
72 F. Manzoni, J. Wallerstein, T. E. Schrader, A. Ostermann, L. Coates, M. Akke, M. P. Blakeley, E. Oksanen and D. T. Logan, J. Med. Chem., 2018, 61, 4412-4420.

73 R. Tellez-Sanz, L. García-Fuentes and A. Vargas-Berenguel, Curr. Med. Chem., 2013, 20, 2979-2990.

74 I. Cumpstey, A. Sundin, H. Leffler and U. J. Nilsson, Angew. Chem., Int. Ed., 2005, 44, 5110-5112.

75 T. Delaine, P. Collins, A. MacKinnon, G. Sharma, J. Stegmayr, V. K. Rajput, S. Mandal, I. Cumpstey, A. Larumbe, B. A. Salameh, B. Kahl-Knutsson, H. van Hattum, M. V. Scherpenzeel, R. J. Pieters, T. Sethi, H. Schambye, S. Oredsson, H. Leffler, H. Blanchard and U. J. Nilsson, ChemBioChem, 2016, 17, 1759-1770.

76 T.-J. Hsieh, H.-Y. Lin, Z. Tu, T.-C. Lin, S.-C. Wu, Y.-Y. Tseng, F.-T. Liu, S.-T. D. Hsu and C.-H. Lin, Sci. Rep., 2016, 6, 29457.

77 V. K. Rajput, A. MacKinnon, S. Mandal, P. Collins, H. Blanchard, H. Leffler, T. Sethi, H. Schambye, B. Mukhopadhyay and U. J. Nilsson, J. Med. Chem., 2016, 59, 8141-8147.

78 F. R. Zetterberg, K. Peterson, R. E. Johnsson, T. Brimert, M. Håkansson, D. T. Logan, H. Leffler and U. J. Nilsson, ChemMedChem, 2018, 13, 133-137.

79 A. Dahlqvist, F. R. Zetterberg, H. Leffler and U. J. Nilsson, Med. Chem. Commun., 2019, 10, 913-925.

80 K. Peterson, R. Kumar, O. Stenström, P. Verma, P. R. Verma, M. Hakansson, B. Kahl-Knutsson, F. Zetterberg, H. Leffler, M. Akke, D. T. Logan and U. J. Nilsson, J. Med. Chem., 2018, 61, 1164-1175.

81 M. A. T. Blaskovich, K. A. Hansford, M. S. Butler, Z. Jia, A. E. Mark and M. A. Cooper, ACS Infect. Dis., 2018, 4, 715-735.

82 V. Kren and T. Rezanka, FEMS Microbiol. Rev., 2008, 32, 858-889.

83 J. Kaplan, B. D. Korty, P. H. Axelsen and P. J. Loll, J. Med. Chem., 2001, 44, 1837-1840.

84 S. Ng, E. Lin, P. I. Kitov, K. F. Tjhung, O. O. Gerlits, L. Deng, B. Kasper, A. Sood, B. M. Paschal, P. Zhang, C.-C. Ling, J. S. Klassen, C. J. Noren, L. K. Mahal, R. J. Woods, L. Coates and R. Derda, J. Am. Chem. Soc., 2015, 137, 5248-5251.

85 S. Behren and U. Westerlind, Molecules, 2019, 24, 100.

86 (a) M. Bergmann, G. Michaud, R. Visini, X. Jin, E. Gillon, A. Stocker, A. Imberty, T. Darbre and J.-L. Reymond, Org. Biomol. Chem., 2016, 14, 138-148; (b) G. Michaud, R. Visini, M. Bergmann, G. Salerno, R. Bosco, E. Gillon, B. Richichi, C. Nativi, A. Imberty, A. Stocker, T. Darbre and J.-L. Reymond, Chem. Sci., 2016, 7, 166-182.

87 C. Bonduelle, H. Oliveira, C. Gauche, J. Huang, A. Heise and S. Lecommandoux, Chem. Commun., 2016, 52, 11251-11254.

88 S.-F. Huang, C.-H. Lin, Y.-T. Lai, C.-L. Tsai, T.-J. R. Cheng and S.-K. Wang, Chem. - Asian J., 2018, 13, 686-700.

89 H. Cai, J. Orwenyo, J. P. Giddens, Q. Yang, R. Zhang, C. C. LaBranche, D. C. Montefiori and L.-X. Wang, Cell Chem. Biol., 2017, 21, 1513-1522. 
90 H. Cai, R. Zhang, J. Orwenyo, J. P. Giddens, Q. Yang, C. C. LaBranche, D. Montefiori and L.-X. Wang, J. Med. Chem., 2018, 61, 10116-10125.

91 A. Escolano, H. B. Gristick, M. E. Abernathy, J. Merkenschlager, R. Gautam, T. Y. Oliveira, J. Pai, A. P. West Jr, C. O. Barnes, A. A. Cohen, H. Wang, J. Golijanin, D. Yost, J. R. Keeffe, Z. Wang, P. Zhao, K. Yao, J. Bauer, L. Nogueira, H. Gao, A. V. Voll, D. C. Montefiori, M. S. Seaman, A. Gazumyan, M. Silva, A. T. McGuire, L. Stamatatos, D. J. Irvine, L. Wells, M. A. Martin, P. J. Bjorkman and M. C. Nussenzweig, Nature, 2019, 570, 468-473.

92 N. Martínez-Sáez, J. M. Peregrina and F. Corzana, Chem. Soc. Rev., 2017, 46, 7154-7175.

93 H. Coelho, T. Matsushita, G. Artigas, H. Hinou, F. J. Cañada, R. Lo-Man, C. Leclerc, E. J. Cabrita, J. JiménezBarbero, S.-I. Nishimura, F. Garcia-Martín and F. Marcelo, J. Am. Chem. Soc., 2015, 137, 12438-12441.

94 N. Martínez-Sáez, J. Castro-López, J. Valero-González, D. Madariaga, I. Compañón, V. J. Somovilla, M. Salvadó, J. L. Asensio, J. Jiménez-Barbero, A. Avenoza, J. H. Busto, G. J. L. Bernardes, J. M. Peregrina, R. Hurtado-Guerrero and F. Corzana, Angew. Chem., 2015, 127, 9968-9972.

95 I. A. Bermejo, I. Usabiaga, I. Compañón, J. Castro-López, A. Insausti, J. A. Fernandez, A. Avenoza, J. H. Busto, J. Jiménez-Barbero, J. L. Asensio, J. M. Peregrina, G. JiménezOsés, R. Hurtado-Guerrero, E. J. Cocinero and F. Corzana, J. Am. Chem. Soc., 2018, 140, 9952-9960.

96 N. Martínez-Sáez, N. T. Supekar, M. A. Wolfert, I. A. Bermejo, R. Hurtado-Guerrero, J. L. Asensio, J. JiménezBarbero, J. H. Busto, A. Avenoza, G.-J. Boons, J. M. Peregrina and F. Corzana, Chem. Sci., 2016, 7, 2294-2301.

97 D. Straßburger, M. Glaffig, N. Stergiou, S. Bialas, P. Besenius, E. Schmitt and H. Kunz, ChemBioChem, 2018, 19, 1142-1146.

98 I. Compañón, A. Guerreiro, V. Mangini, J. Castro-López, M. Escudero-Casao, A. Avenoza, J. H. Busto, S. Castillón, J. Jiménez-Barbero, J. L. Asensio, G. Jiménez-Osés, O. Boutureira, J. M. Peregrina, R. Hurtado-Guerrero, R. Fiammengo, G. J. L. Bernardes and F. Corzana, J. Am. Chem. Soc., 2019, 141, 4063-4072.

99 V. J. Somovilla, I. A. Bermejo, I. S. Albuquerque, N. Martínez-Sáez, J. Castro-López, F. Garcia Martin, I. Compañón, H. I. Hinou, S.-I. Nishimura, J. JiménezBarbero, J. L. Asensio, A. Avenoza, J. H. Busto, R. HurtadoGuerrero, J. M. Peregrina, G. J. L. Bernardes and F. Corzana, J. Am. Chem. Soc., 2017, 139, 18255-18261.

100 B. Palitzsch, N. Gaidzik, N. Stergiou, S. Stahn, S. Hartmann, B. Gerlitzki, N. Teusch, P. Flemming, E. Schmitt and H. Kunz, Angew. Chem., Int. Ed., 2016, 55, 2894-2898.

101 X. Wu, Z. Yin, C. McKay, C. Pett, J. Yu, M. Schorlemer, T. Gohl, S. Sungsuwan, S. Ramadan, C. Baniel, A. Allmon, R. Das, U. Westerlind, M. G. Finn and X. Huang, J. Am. Chem. Soc., 2018, 140, 16596-16609.

102 M. A. Wolfert and G.-J. Boons, Nat. Chem. Biol., 2013, 9, 776-784.
103 L. Sun, D. R. Middleton, P. L. Wantuch, A. Ozdilek and F. Y. Avic, Glycobiology, 2016, 26, 1029-1040.

104 F. Berti and R. Adamo, Chem. Soc. Rev., 2018, 47, 9015-9025.

105 (a) T.-C. Chang, Y. Manabe, Y. I. Fujimoto, S. Ohshima, Y. Kametani, K. Kabayama, Y. Nimura, C.-C. Lin and K. I. Fukase, Angew. Chem., Int. Ed., 2018, 57, 8219-8224; (b) M.-M. Wei, Y. S. Wang and X. S. Ye, Med. Res. Rev., 2018, 38, 1003-1026.

106 (a) C. Colombo, O. Pitirollo and L. Lay, Molecules, 2018, 23, 1712; (b) S. A. Krumm and K. J. Doores, Current Topics in Microbiology and Immunology, Springer, Berlin, Heidelberg, 2018; (c) J. Hütter and B. Lepenies, Methods Mol. Biol., 2015, 1331, 1-10.

107 C. L. Anish, B. Schumann, C. L. Pereira and P. H. Seeberger, Chem. Biol., 2014, 21, 38-50.

108 P. Kaplonek, N. Khan, K. Reppe, B. Schumann, M. Emmadi, M. P. Lisboa, F.-F. Xu, A. D. J. Calow, S. G. Parameswarappa, M. Witzenrath, C. L. Pereira and P. H. Seeberger, Proc. Natl. Acad. Sci. U. S. A., 2018, 115, 13353-13358.

109 (a) T. C. Stevenson, C. Cywes-Bentley, T. D. Moeller, K. B. Weyant, D. Putnam, Y.-F. Chang, B. D. Jones, G. B. Pier and M. P. DeLisa, Proc. Natl. Acad. Sci. U. S. A., 2018, 115, E3106-E3115; (b) F. Micoli, S. Rondini, R. Alfini, L. Lanzilao, F. Necchi, A. Negrea, O. Rossi, C. Brandt, S. Clare, P. Mastroeni, R. Rappuoli, A. Saul and C. A. MacLennan, Proc. Natl. Acad. Sci. U. S. A., 2018, 115, 10428-10433.

110 Q. Li and Z. Guo, Molecules, 2018, 23, 1583.

111 X. Sun, G. Stefanetti, F. Berti and D. L. Kasper, Proc. Natl. Acad. Sci. U. S. A., 2019, 116, 193-198.

112 S. Carillo, S. Mittermayr, A. Farrell, S. Albrecht and J. Bones, Methods Mol. Biol., 2017, 1603, 227-241.

113 B. Bobaly, V. D'Atri, A. Goyon, O. Colas, A. Beck, S. Fekete and D. Guillarme, J. Chromatogr. B: Anal. Technol. Biomed. Life Sci., 2017, 1060, 325-335.

114 A. Resemann, W. Jabs, A. Wiechmann, E. Wagner, O. Colas, W. Evers, E. Belau, L. Vorwerg, C. Evans, A. Beck and D. Suckau, $m A b s, 2016,8,318-330$.

115 D. Reusch and M. L. Tejada, Glycobiology, 2015, 25, 1325-1334.

116 L. Liu, J. Pharm. Sci., 2015, 104, 1866-1884.

117 E. Largy, F. Cantais, G. Van Vyncht, A. Beck and A. Delobel, J. Chromatogr. A, 2017, 1498, 128-146.

118 A. Planinc, B. Dejaegher, Y. V. Heyden, J. Viaene, S. Van Praet, F. Rappez, P. Van Antwerpen and C. Delporte, Anal. Bioanal. Chem., 2017, 409, 477-485.

119 J. Giorgetti, V. D'Atri, J. Canonge, A. Lechner, D. Guillarme, O. Colas, E. Wagner-Rousset, A. Beck, E. Leize-Wagner and Y. François, Talanta, 2018, 178, 530-537.

120 L. Zhang, S. Luo and B. Zhang, $m A b s, 2016,8$, 205-215.

121 L. Zhang, S. Luo and B. Zhang, $m A b s, 2016,8$, 524-535.

122 F. Cymera, H. Beck, A. Rohde and D. Reusch, Biologicals, 2018, 52, 1-11.

123 F. Higel, A. Seidl, F. Sörgel and W. Friess, Eur. J. Pharm. Biopharm., 2016, 100, 94-100. 
124 E. O. Saphire, P. W. H. I. Parren, R. Pantophlet, M. B. Zwick, G. M. Morris, P. M. Rudd, R. A. Dwek, R. L. Stanfield, D. R. Burton and L. A. Wilson, Science, 2001, 293, 1155-1159.

125 W. Li, Z. Zhu, W. Chen, Y. Feng and D. S. Dimitrov, Front. Immunol., 2017, 8, 1554.

126 D. Venetz, C. Hess, C. Lin, M. Aebi and D. Neri, Proc. Natl. Acad. Sci. U. S. A., 2015, 112(7), 2000-2005.

127 B. Hintersteiner, N. Lingg, E. Janzek, O. Mutschlechner, H. Loibner and A. Jungbauer, Biotechnol. J., 2016, 11(12), 1617-1627.

128 A. W. Barb, D. J. Falconer and G. P. Subedi, Methods Enzymol., 2019, 614, 239-261.

129 S. Yanaka, H. Yagi, R. Yogo, M. Y. Utsumi and K. Kato, J. Biomol. NMR, 2018, 71, 193-202.

130 M. Dicker and R. Strasser, Expert Opin. Biol. Ther., 2015, 15(10), 1501-1516.

131 Q. Yang and L. Wang, Methods Enzymol., 2017, 597, 265-281.

132 Y. Mimura, T. Kato, R. Saldova, R. O'Flaherty, T. Izumi, Y. Mimura-Kimura, T. Utsunomiya, Y. Mizukami, K. Yamamoto, T. Matsumoto and P. M. Rudd, Protein Cell, 2018, 9, 47-62.

133 A. J. Fairbanks, Chem. Soc. Rev., 2017, 46, 5128-5146.

134 T. B. Parsons, W. B. Struwe, J. Gault, K. Yamamoto, T. A. Taylor, R. Raj, K. Wals, S. Mohammed, C. V. Robinson, J. L. P. Benesch and B. G. Davis, Angew. Chem., Int. Ed., 2016, 55, 2361-2367.
135 T. Nagasu, Y. Shimma, Y. Nakanishi, J. Kuromitsu, K. Iwama, K. Nakayama, K. Suzuki and Y. Jigami, Yeast, 1992, 8, 535-547.

136 H. Abe, Y. Takaoka, Y. Chiba, N. Sato, S. Ohgiya, A. Itadani, M. Hirashima, C. Shimoda, Y. Jigami and K. Nakayama, Glycobiology, 2009, 19, 428-436.

137 C. Unverzagt and Y. Kajihara, Curr. Opin. Chem. Biol., 2018, 46, 130-137.

138 G.-M. Fang, Y.-M. Li, F. Shen, Y.-C. Huang, J.-B. Li, Y. Lin, H.-K. Cui and L. Liu, Angew. Chem., Int. Ed., 2011, 50, 7645-7649.

139 R. Chang, A. Al Maghribi, V. Vanderpoel, A. Ing, V. Vasilevko, D. H. Cribbs, R. Boado, W. M. Pardridge and R. Sumbria, Alzheimer's Dementia, 2018, 14, 1086-1087.

140 W. Liu, L. Wen, T. Xie, H. Wang, J. Gong and X. Yang, J. Neurosurg., 2016, 127, 1-8.

141 A. Tankiewicz-Kwedlo, J. M. Hermanowicz, T. Domaniewski, K. Pawlak, M. Rusak, A. Pryczynicz, A. Surazynski, T. Kaminski, A. Kazberuk and D. Pawlak, Br. J. Pharmacol., 2018, 175, 743-762.

142 S. Rasaneh and M. R. Dadras, Biomed. Tech., 2015, 60, 485-490.

143 A. Kesavan, P. Ilaiyaraja, W. S. Beaula, V. V. Kumari, J. S. Lal, C. Arunkumar, G. Anjana, S. Srinivas, A. Ramesh, S. K. Rayala, D. Ponraju and G. Venkatraman, Eur. J. Pharm. Biopharm., 2015, 96, 255-263. 